\title{
Biofilm inhibition activity of traditional medicinal plants from Northwestern Argentina against native pathogen and environmental microorganisms
}

\author{
Cintia Mariana Romero ${ }^{[1],[2], ~ C r i s t i a n ~ G e r m a ́ n ~ V i v a c q u a ~}{ }^{[1]}$, María Belén Abdulhamid ${ }^{[1],}$ \\ Mario Domingo Baigori ${ }^{[1],[2]}$, Alberto Carlos Slanis ${ }^{[3]}$, María Cristina Gaudioso de Allori ${ }^{[2]}$ \\ and María Laura Tereschuk ${ }^{[4]}$
}

\begin{abstract}
[1]. Planta Piloto de Procesos Industriales Microbiológicos, Consejo Nacional de Investigaciones Científicas y Técnicas, San Miguel de Tucumán, Tucumán, Argentina. [2]. Facultad de Bioquímica, Química, Farmacia y Biotecnología, Universidad Nacional de Tucumán, San Miguel de Tucumán, Tucumán, Argentina. [3]. Facultad de Ciencias Naturales e Instituto Miguel Lillo, San Miguel de Tucumán, Tucumán, Argentina. [4]. Cátedra de Química Orgánica, Facultad de Ciencias Exactas y Tecnología, Universidad Nacional de Tucumán, San Miguel de Tucumán, Tucumán, Argentina.
\end{abstract}

\begin{abstract}
Introduction: Plants have been commonly used in popular medicine of most cultures for the treatment of disease. The in vitro antimicrobial activity of certain Argentine plants used in traditional medicine has been reported. The aim of this study was to investigate the antimicrobial, anti-biofilm, and anti-cell adherence activities of native plants (Larrea divaricata, Tagetes minuta, Tessaria absinthioides, Lycium chilense, and Schinus fasciculatus) collected in northwestern Argentina. Methods: The activities of the five plant species were evaluated in Bacillus strains and clinical strains of coagulase-negative Staphylococcus isolated from northwestern Argentina and identified by 16S rDNA. Result: Lycium chilense and Schinus fasciculatus were the most effective antimicrobial plant extracts $(15.62 \mu \mathrm{g} / \mathrm{ml}$ and $62.50 \mu \mathrm{g} / \mathrm{ml}$ for Staphylococcus sp. Mcr1 and Bacillus sp. Mcn4, respectively). The highest (66\%) anti-biofilm activity against Bacillus sp. Mcn4 was observed with T. absinthioides and L. divaricate extracts. The highest (68\%) anti-biofilm activity against Staphylococcus sp. Mcr1 was observed with L. chilense extract. T. minuta, T. absinthioides, and $L$. divaricata showed percentages of anti-biofilm activity of between $55 \%$ and $62 \%$. The anti-adherence effects of T. minuta and L. chilense observed in Bacillus sp. Mcn4 reflected a difference of only $22 \%$ and $10 \%$, respectively, between anti-adherence and biofilm inhibition. Thus, the inhibition of biofilm could be related to cell adherence. In Staphylococcus sp. Mcr1, all plant extracts produced low anti-adherence percentages. Conclusion: These five species may represent a source of alternative drugs derived from plant extracts, based on ethnobotanical knowledge from northwest Argentina.
\end{abstract}

Keywords: Anti-biofilm. Traditional medicinal plant. Bacillus. Staphylococcus.

\section{INTRODUCTION}

Resistance to antibiotics has become a major public health problem worldwide as it reduces the effectiveness of treatments and increases morbidity, mortality, and health-care $\operatorname{costs}^{(1)}$. This challenge is a natural consequence of the adaption of infectious pathogens to the types of antimicrobials used in multiple areas, including medicines, plants and animals raised as food, and disinfectants used in farms, hospitals, and households ${ }^{(2)(3)}$.

Research on plants as potential sources of new and effective antimicrobials with novel modes of action is well established. Although active constituents may occur in plants in low concentrations, plant extracts may, in many cases, represent a superior source of antimicrobial compounds than synthetic drugs ${ }^{(4)}$.

Corresponding author: Dra. Cintia Mariana Romero.

e-mail: cinromero78@gmail.com

Received 5 February 2016

Accepted 14 October 2016
The use of plants for the treatment of multiple ailments has been a common practice in the popular medicine of most cultures, even where the precise causation of a disease and/or the mechanisms of its cure have not always been understood ${ }^{(5)(6)}$. Exploratory research on plants as sources of new antimicrobial compounds has led to a joint interest in fundamental research in the fields of agriculture, chemistry, and medicine. However, studies on the antimicrobial activity of plant extracts have been largely restricted to the analysis of their bacteriostatic and bactericidal properties ${ }^{(7)}$.

There are some existing reports on the in vitro antimicrobial activity of ethanolic extracts of some Argentine plants used in traditional medicine ${ }^{(8)}{ }^{(9)}$, although few studies evaluating antimicrobial activity as well as anti-biofilm activity in relation to pathogenic microorganisms have been reported ${ }^{(10)(11)}$. Biofilm is the predominant mode of growth for bacteria in most natural, industrial, and clinical environments. Biofilms typically consist of densely packed, multi-species populations 
of cells, encased in a self-synthesized polymeric matrix and attached to a tissue or surface ${ }^{(12)}$. This mode of growth protects bacteria from environmental stresses, that is, the treatment of biofilms with antibiotics or other biocides is often ineffective for eradication ${ }^{(13)}$. Biofilm formation is therefore a major challenge in many contexts, ranging from industrial corrosion and biofouling ${ }^{(14)}$ to chronic and nosocomial infections ${ }^{(15)}$.

The purpose of the present work was therefore to investigate and demonstrate the presence of antimicrobial, anti-biofilm, and anti-adherence activities in native plants collected in northwestern Argentina (specifically, Larrea divaricata, Tagetes minuta, Tessaria absinthioides, Lycium chilense, and Schinus fasciculatus), which have been traditionally used for a variety of folk medicinal purposes.

\section{METHODS}

\section{Microorganisms and fermentation conditions}

Bacillus strains were isolated from a variety of sources in northwestern Argentina, such as soils contaminated with hydrocarbons and natural soils from a riverbank. Soil suspensions were created and heated at $80^{\circ} \mathrm{C}$ for $15 \mathrm{~min}$, plated onto Luria-Bertani (LB) agar, and incubated at $37^{\circ} \mathrm{C}$. Clinical isolates of coagulase-negative Staphylococcus (CoNS) were also obtained from a dialysis center in the City of San Miguel de Tucumán. All isolated bacteria were characterized using conventional biochemical methods, namely catalase, bacitracin susceptibility, and coagulase testing. Liquid cultures of Bacillus and CoNS were prepared in $125-\mathrm{ml}$ flasks containing $10 \mathrm{ml}$ of LB medium on an orbital shaker at $37^{\circ} \mathrm{C}$.

\section{Molecular characterization}

Total deoxyribonucleic acid (DNA) was extracted from cells harvested in the mid-exponential growth phase as described previously ${ }^{(16)}$. Polymerase chain reaction (PCR) amplification was performed in a $25-\mu 1$ reaction mix containing $2.5 \mu 1$ 10X STR reaction buffer (Promega, Wisconsin, United States), 20ng total DNA, $0.5 \mu \mathrm{M}$ of each primer, and $1 \mathrm{U}$ Taq DNA polymerase (Promega). Primers of the sequence 27F (5'-AGAGTTTGATCMTGGCTCAG-3') and 1492R (5'-GGTTACCTTGTTACGACTT-3') were used to generate partial sequences of $16 \mathrm{~S}$ ribosomal DNA(rDNA). Amplification conditions were as follows: $5 \mathrm{~min}$ at $94^{\circ} \mathrm{C} ; 35$ cycles of $1 \mathrm{~min}$ at $94^{\circ} \mathrm{C}, 2 \mathrm{~min}$ at $50^{\circ} \mathrm{C}$, and $2 \min$ at $72^{\circ} \mathrm{C}$; and $7 \mathrm{~min}$ at $72^{\circ} \mathrm{C}$ for the final extension. PCR products were analyzed by electrophoresis on $2 \%(\mathrm{wt} / \mathrm{vol})$ agarose gels.

DNA sequencing was performed by Macrogen Services(Seoul, South Korea). Sequences were compared and aligned with the GenBank database using Basic Local Alignment Search Tool (BLAST) software. Partial nucleotide sequences of the 16S rDNA gene of Bacillus sp. and CoNS Staphylococcus sp. were deposited in the GenBank database under accession numbers KP872905 and KP872906, respectively.

\section{Plant material and extraction}

In the present study, samples of five native plants from four families were collected in order to evaluate their antibacterial and/or anti-biofilm activities (Table 1) 1 (17)(18)(19) (20)(21) (22) (23) (24) (25) (26) (27) (28) (29) (30)(31). The leaves of these plants were collected in the locality of Tafí del Valle in the province of Tucumán in northwestern Argentina (Figure 1A). We focused our study on leaves because they represent a sustainable resource and, although bark has been traditionally used, leaf extracts tend to show higher activity. The identity of the plant material was confirmed and voucher specimens were entered into the Miguel Lillo Herbarium at the National University of Tucuman. Botanical and vernacular names, traditional uses, and reported chemical compositions are shown in Table 1. The collected leaves were dried at room temperature in a well-ventilated room and ground to fine powder using a mortar and pestle. This powder was then macerated in $80 \%$ ethanol for $48 \mathrm{~h}$ and then filtered through Whatman $n^{\circ} 1$ filter paper.

The solid residue was suspended in 50\% ethanol until dissolution. The extracts were then concentrated to dryness using a rotary evaporator (Figmay, Córdoba Argentina) under reduced pressure and at a temperature not exceeding $50^{\circ} \mathrm{C}$. For antimicrobial and anti-biofilm studies, several concentrations of each prepared powder were evaluated $(8-500 \mu \mathrm{g} / \mathrm{ml})$.

\section{Determination of sub-inhibitory concentration and mini- mum inhibitory concentration}

The microorganisms used in this study were cultured in Mueller-Hinton (MH) broth and incubated at $37^{\circ} \mathrm{C}$ for $24 \mathrm{~h}$ prior to assays. All cultures were standardized by standard dilution in $\mathrm{MH}$ broth $\left(4^{\circ} \mathrm{C}\right)$ and characterized by experimental transmittance $\left[\mathrm{T}=30\right.$, optical density $\left.(\mathrm{OD})_{610}\right]$. Growth at $4^{\circ} \mathrm{C}$ was stopped by immersion in ice-cold water. From this standard dilution, a $50 \mathrm{ml}$ working suspension was prepared with corrected transmittance $\mathrm{T}=95(25 \mu \mathrm{l}$ of $\mathrm{T}=30 \mathrm{in} 5 \mathrm{ml}$ of refrigerated $\mathrm{MH}$ broth), corresponding to $1.5 \times 10^{8}$ colonyforming units $(\mathrm{CFU}) / \mathrm{ml}$ for the Bacillus sp. strain and $1.2 \times$ $10^{8} \mathrm{CFU} / \mathrm{ml}$ for the Staphylococcus sp. strain. This dilution was maintained at $4^{\circ} \mathrm{C}$ to ensure cellular quiescence. Inoculum $(100 \mu l)$ was added to each well containing sample plant extracts.

The effect of plant extracts on the growth of Bacillus and CoNS Staphylococcus isolates was evaluated using a standard broth microdilution methodology. Serial dilution was employed to determine the minimum inhibitory concentration (MIC) [the lowest plant metabolite concentration $(\mu \mathrm{g} / \mathrm{ml})$ that inhibited bacterial growth] and sub-inhibitory concentration (SIC) [the highest extract concentration $(\mu \mathrm{g} / \mathrm{ml})$ below the MIC that did not inhibit bacterial growth] concentrations in the range $8-500 \mu \mathrm{g} / \mathrm{ml}$ after $24 \mathrm{~h}$ of growth.

The plant extracts at each concentration were prepared in dimethyl sulfoxide (DMSO) solvent, aliquoted into multi-well polystyrene plates, and dried to allow DMSO evaporation (to avoid the toxic effects of DMSO on bacteria). Negative controls (cells + MH broth), positive controls [cells + MH broth + antibiotics (chloramphenicol and gentamicin)], and media controls (MH) were included. Positive controls for antibiotics were prepared at $8-500 \mu \mathrm{g} / \mathrm{ml}$ using serial dilution. All tests were performed in quadruplicate.

Plates were incubated at $37^{\circ} \mathrm{C}$ for $24 \mathrm{~h}$. To determine growth, absorbance was read at $610 \mathrm{~nm}$ using a microplate reader 
TABLE 1

Botanical and common names, traditional uses, and reported chemical compositions of five native plants (Larrea divaricata, Tagetes minuta, Tessaria absinthioides, Lycium chilense, and Schinus fasciculatus) from Tafi del Valle, Tucumán, northwestern Argentina.

\begin{tabular}{|c|c|c|c|c|c|c|}
\hline Botanical name & Family & $\begin{array}{l}\text { Collection } \\
\text { site }\end{array}$ & Coordinates & Voucher ID & $\begin{array}{l}\text { Chemical } \\
\text { composition }\end{array}$ & $\begin{array}{c}\text { Ethnobotanical } \\
\text { uses }\end{array}$ \\
\hline Larrea divaricata Cav. & Zygophyllaceae & $\begin{array}{l}\text { Ampimpa } \\
\text { (Dpt. Tafí del Valle) }\end{array}$ & $\begin{array}{l}\mathrm{S} 26^{\circ} 36,519^{\prime} \\
\mathrm{W} 65^{\circ} 50,678^{\prime}\end{array}$ & $\begin{array}{l}\text { Slanis et al. } 3427 \\
\text { (LIL) }\end{array}$ & $\begin{array}{l}\text { Lignans, flavonoids } \\
\text { as quercetin }^{(17)}\end{array}$ & $\begin{array}{l}\text { Tuberculosis, } \\
\text { common cold, } \\
\text { antitumor, } \\
\text { antifungal }^{(18)}\end{array}$ \\
\hline Schinus fasciculatus L. & Anacardiaceae & $\begin{array}{l}\text { Amaicha } \\
\text { (Dpt. Tafí del Valle) }\end{array}$ & $\begin{array}{l}\mathrm{S} 26^{\circ} 35,632^{\prime} \\
\mathrm{W}^{\circ} 5^{\circ} 54,953^{\prime}\end{array}$ & $\begin{array}{l}\text { Slanis et al. } 3427 \\
\text { (LIL) }\end{array}$ & $\begin{array}{l}\text { Sesquiterpene, } \\
\text { terpenoids, } \\
\text { flavonoids, } \\
\text { saponins, sterols, } \\
\text { essential oils, gums } \\
\text { and resins } \\
(20)(30)(5)(21)\end{array}$ & $\begin{array}{l}\text { Antibacterial and } \\
\text { antifungal } \\
\text { activity }^{(22)}\end{array}$ \\
\hline Tagetes minuta $\mathrm{L}$. & Asteraceae & $\begin{array}{l}\text { Road } 307 \text { km } 53 \\
\text { (Dpt. Tafí del Valle) }\end{array}$ & $\begin{array}{l}\mathrm{S} 26^{\circ} 53^{\prime} 6,49^{\prime \prime} \\
\mathrm{W} 65^{\circ} 41^{\prime} 28,40^{\prime}\end{array}$ & $\begin{array}{l}\text { Slanis et al. } 3125 \\
\text { (LIL) }\end{array}$ & $\begin{array}{l}\text { Essential oils, } \\
\text { terpenoids, } \\
\text { flavonoids as } \\
\text { quercetagetin, } \\
\text { patiletin, } \\
\text { isorhamnetin }\end{array}$ & $\begin{array}{l}\text { Antimicrobial }{ }^{(25)(26)} \\
\text { antioxidant }^{(27(6)} \text {, } \\
\text { repellent }^{(28)} \text {, } \\
\text { and acaricide } \\
\text { activity }{ }^{(29)}\end{array}$ \\
\hline $\begin{array}{l}\text { Tessaria absinthioides } \\
\text { (Hook \&Arn.) ex DC. }\end{array}$ & Asteraceae & $\begin{array}{l}\text { Los Zazos } \\
\text { (Dpt. Tafí del Valle) }\end{array}$ & $\begin{array}{l}\mathrm{S} 26^{\circ} 36,189^{\prime} \\
\mathrm{W} 65^{\circ} 54,074^{\prime},\end{array}$ & $\begin{array}{l}\text { Slanis et al. } 3428 \\
\text { (LIL) }\end{array}$ & $\begin{array}{l}\text { Sesquiterpene, } \\
\text { sulfur compounds, } \\
\text { flavonoids, essential } \\
\text { oils }^{(30)}\end{array}$ & $\begin{array}{l}\text { Antiviral } \\
\text { activity }^{(31)}\end{array}$ \\
\hline
\end{tabular}

(Thermo Scientific ${ }^{\mathrm{TM}}$ Multiskan ${ }^{\mathrm{TM}}$ GO Ultraviolet-Visible microplate spectrophotometer,United States ). To determine the effects of the extracts, a formula was used to calculate percent inhibition. The mean percentage of inhibition from the replicates was used to determine the final MIC and SIC values ${ }^{(7)}$.

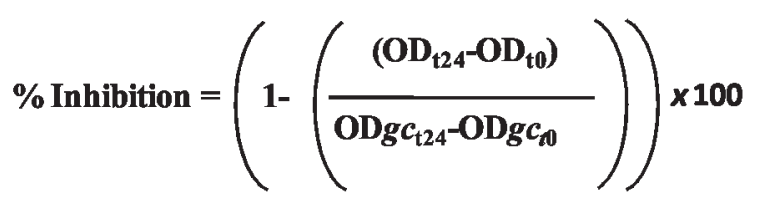

$\mathrm{OD}_{\mathrm{t} 24}=$ optical density $(610 \mathrm{~nm})$ of the test well at 24 hours post-inoculation

$\mathrm{OD}_{\mathrm{t} 0}=$ optical density $(610 \mathrm{~nm})$ of the test well at 0 hours postinoculation

$\mathrm{OD} g c_{t 24}=$ optical density $(610 \mathrm{~nm})$ of the growth control well at 24 hours post-inoculation $\mathrm{OD} g c_{\mathrm{t} 0}=$ optical density $(610 \mathrm{~nm})$ of the growth control well at 0 hours post-inoculation

\section{Biofilm formation and anti-biofilm effects of plant extracts}

Biofilm production was carried out with the method in polystyrene multi-well cell culture plates. The biofilmproducing CoNS Staphylococcus strains 263 and 1174 (isolated from bovine mastitis and provided by the Faculty of Veterinary Medicine, Buenos Aires University) and a non-producing CoNS Staphylococcus strain (ATCC 12228) were used as controls ${ }^{(1)}$.

The inoculum of each microorganism was standardized through standard dilution with $\mathrm{LB}\left(4^{\circ} \mathrm{C}\right)$ and characterized by experimental transmittance $\left(\mathrm{T}=30, \mathrm{OD}_{610}\right)$. From this standard dilution, a $50 \mathrm{ml}$ working suspension was prepared with corrected transmittance $\mathrm{T}=95(25 \mu \mathrm{l}$ of $\mathrm{T}=30$ in $5 \mathrm{ml}$ of $\mathrm{LB}$ broth at $4^{\circ} \mathrm{C}$ ) corresponding to $9 \times 10^{8} \mathrm{CFU} / \mathrm{ml}$ for Bacillus sp. strain and $1.6 \times 10^{8} \mathrm{CFU} / \mathrm{ml}$ for Staphylococcus sp. strain. To detect biofilm-producing bacteria, $100 \mu \mathrm{l}$ of inoculum from each bacterial suspension and medium control (LB broth) were deposited in triplicate on multi-well polystyrene plates, and the plates were incubated at $37^{\circ} \mathrm{C}$ for $24 \mathrm{~h}$. After incubation, 
medium was extracted by inversion and wells were washed twice with phosphate-buffered saline (PBS) $\left(8.1 \mathrm{mM} \mathrm{Na}_{2} \mathrm{HPO}_{4}, 1.5 \mathrm{mM}\right.$ $\mathrm{KH}_{2} \mathrm{PO}_{4}, 140 \mathrm{mM} \mathrm{NaCl}$, and $3 \mathrm{mM} \mathrm{KCl} ; \mathrm{pH}$ 7.2). The contents of wells were emptied by inversion and plates were dried upside-down on absorbent paper. Once dry, biofilms appeared as whitish, opaque membranes and were fixed with methanol for $7 \mathrm{~min}^{(32)}$. Plates were emptied again by inversion and air-dried. Once dry, an aqueous solution of $0.1 \%$ safranin was used as a stain. After $4 \mathrm{~min}$, plates were again inverted, washed with water, dried upside-down ${ }^{(1)}$.

Biofilm formation was evaluated using a microplate reader at $490 \mathrm{~nm}$ (Thermo Scientific ${ }^{\mathrm{TM}}$ Multiskan ${ }^{\mathrm{TM}}$ GO UltravioletVisible microplate spectrophotometer,United States). The strains considered as the best producers of biofilm were those with $\mathrm{OD}_{490}$ values greater than those of the control strains $\left(\mathrm{OD}_{490}>0.08\right)^{(1)}$.

Next, the selected bacterial strains were analyzed in the absence and presence of plant extracts. To determine the effects of plant extracts on biofilm formation, SIC of plant extracts $(10-100 \mu \mathrm{g} / \mathrm{ml}$ as appropriate for each microorganism) were added to the test wells and allowed to dry prior to inoculation. Inoculum (corresponding to $9 \times 10^{8} \mathrm{CFU} / \mathrm{ml}$ for Bacillus sp. strain and $1.6 \times 10^{8} \mathrm{CFU} / \mathrm{ml}$ for Staphylococcus sp. strain) was added in the form of a bacterial suspension at the zero hour time point of biofilm formation, and biofilms were allowed to develop for $24 \mathrm{~h}$ as described above. Each bacterial strain inoculated in the absence of a plant extract was considered as a positive control for biofilm formation.

\section{Bacterial adhesion assay}

Inoculum was prepared as a 1:10 dilution of microorganism cultures (24h) using fresh LB broth followed by incubation at $37^{\circ} \mathrm{C}$ for $2 \mathrm{~h}$ with shaking at $100 \mathrm{rpm}$ (inoculum had $\mathrm{OD}_{610}=0.100$, corresponding to $\left.1.5 \times 10^{8} \mathrm{CFU} / \mathrm{ml}\right)$. Inoculum of $200 \mu \mathrm{l}$ was then added to multi-well polystyrene plates at $37^{\circ} \mathrm{C}$ for $3 \mathrm{~h}$ in the presence and absence of plant extracts at SIC. Next, the medium wasextracted by inversion, plates were washed twice with PBS, and bacterial adhesions were fixed with $25 \%$ formaldehyde for $30 \mathrm{~min}$. Wells were then dried and stained with $0.1 \%$ safranin. Cell adherence measurement was carried out in a microplate reader at $490 \mathrm{~nm}$. The percentage of inhibition of bacterial adhesion was determined as described above.

\section{Statistical analysis}

Statistical analysis was performed using SigmaPlot 12.0 and Minitab (Minitab, Inc.) software version 14 for Windows. Normality distribution was evaluated by Shapiro-Wilk test and analysis of variance (ANOVA) was used to evaluate the mean differences among treatments. Two-way ANOVA and subsequent comparisons were performed using the Holm-Sidak test and Bonferroni post-test as appropriate. Results were presented as the mean Standard Deviation (SD), and differences were accepted as significant for $\mathrm{p}<0.05$ ( $5 \%$ of the significance level).

\section{RESULTS}

\section{Isolation and selection of indigenous spore-forming bacteria and coagulase-negative Staphylococcus strains}

A total of 53 spore-forming bacteria were isolated from natural environments, and $22 \mathrm{CoNS}$ strains were isolated from a dialysis center ${ }^{(1)}$. From this total of 75 native isolates, 24 were selected as biofilm producers and the Mcn4 and Mcr1 strains were identified as the best biofilm producers compared with control strains (Figure 1B). Partial sequencing of the 16S rDNA gene confirmed the biochemical and morphological characterization of both strains. A BLAST search and alignment analysis showed a similarity of $99 \%$ for strain Men 4 with Bacillus licheniformis, hereinafter referred to as Bacillus sp. Mcn4; and strain Mcr1 with Staphylococcus sciuri, hereinafter referred to as Staphylococcus sp. Mcr1.

\section{Determination of sub-inhibitory concentration and minimum inhibitory concentration}

Table 2 shows the SIC and MIC values obtained for the five plant extracts. These results reflect a variable degree of antibacterial activity against the Bacillus and Staphylococcus genera, and indicate that dose-dependent antimicrobial activity was observed for all plant extracts.

Extracts from L. chilense and S. fasciculatus showed the best antimicrobial properties, with SIC values of $62.50 \mu \mathrm{g} / \mathrm{ml}$ for Bacillus sp. Mcn 4 and $15.62 \mu \mathrm{g} / \mathrm{ml}$ for Staphylococcus sp. Mcr1 for both extracts (Table 2). Furthermore, both L. chilense and $S$. fasciculatus showed antimicrobial activity against Bacillus strains, with an SIC value of $62.50 \mu \mathrm{g} / \mathrm{ml}$, the same SIC observed for chloramphenicol (Table 2). The antimicrobial activities shown by the genera Schinus and Lycium against Staphylococcus sp. Mcrl included SIC values equal to those observed for gentamicin $(15.62 \mu \mathrm{g} / \mathrm{ml})$.

A moderate level of antimicrobial activity (SIC 125-250 $\mu \mathrm{g} /$ ml) was observed against Bacillus sp. Mcn4 for T. minuta, T. absinthioides, and $L$. divaricata (Table 2). However, these plant extracts showed high antimicrobial activity against Staphylococcus sp. Mcr1. It is notable that all plant extracts

\section{TABLE 2}

Effects of Larrea divaricata, Tagetes minuta, Tessaria absinthioides, Lycium chilense, and Schinus fasciculatus on the viability of bacteria from the genera Bacillus and Staphylococcus.

\begin{tabular}{lcccc}
\hline Plant name & $\begin{array}{c}\text { Bacillus licheniformis } \\
\text { MIC }^{\mathbf{1}}(\boldsymbol{\mu g} / \mathbf{m l})\end{array}$ & $\begin{array}{c}\text { Stc } \\
\text { Staphylococcus sciuri } \\
\mathbf{M I C}^{\mathbf{1}}(\boldsymbol{\mu g} / \mathbf{m l}) \mathbf{S I C}^{2}\end{array}$ \\
\hline Schinus fasciculatus & 125 & 62.50 & 31.25 & 15.62 \\
Tagetes minuta & 500 & 250 & 62.5 & 31.25 \\
Tessaria absinthioides & 250 & 125 & 125 & 62.50 \\
Lycium chilense & 125 & 62.50 & 31.25 & 15.62 \\
Larrea divaricata & 250 & 1250 & 31.25 & 15.62 \\
Gentamicin & & 15.62 & & 15.62 \\
Chloramphenicol & & 62.50 & & 62.50 \\
\hline
\end{tabular}

MIC $(\mu \mathrm{g} / \mathrm{ml})$ and SIC $(\mu \mathrm{g} / \mathrm{ml})$ were determined, with values expressed as means from triplicate assays. ${ }^{1} \mathrm{MIC}=$ the lowest plant metabolite concentration $(\mu \mathrm{g} / \mathrm{ml})$ that inhibited bacterial growth. ${ }^{2} \mathrm{SIC}=$ the highest extract concentration $(\mu \mathrm{g} / \mathrm{ml})$ below the MIC that did not inhibit bacterial growth. MIC: miminimum inhibitory concentration; SIC: sub-inhibitory concentration. 
(A)

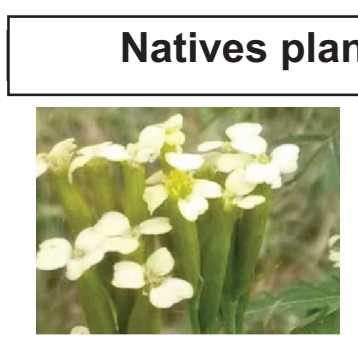

Tagetes minuta

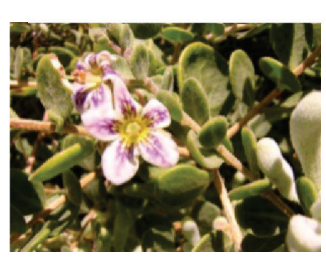

Lycium chilense

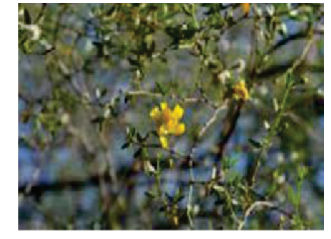

Larrea divaricata
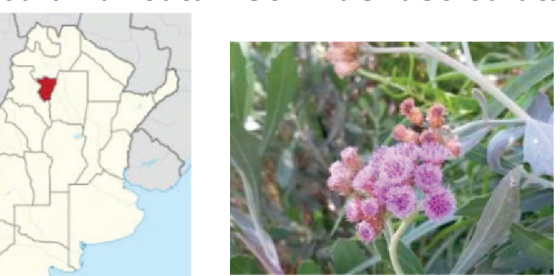

Tessaria absinthioides

Antimicrobial activity

(MIC and SIC)
(B)

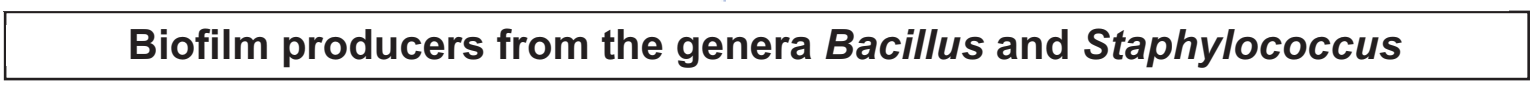

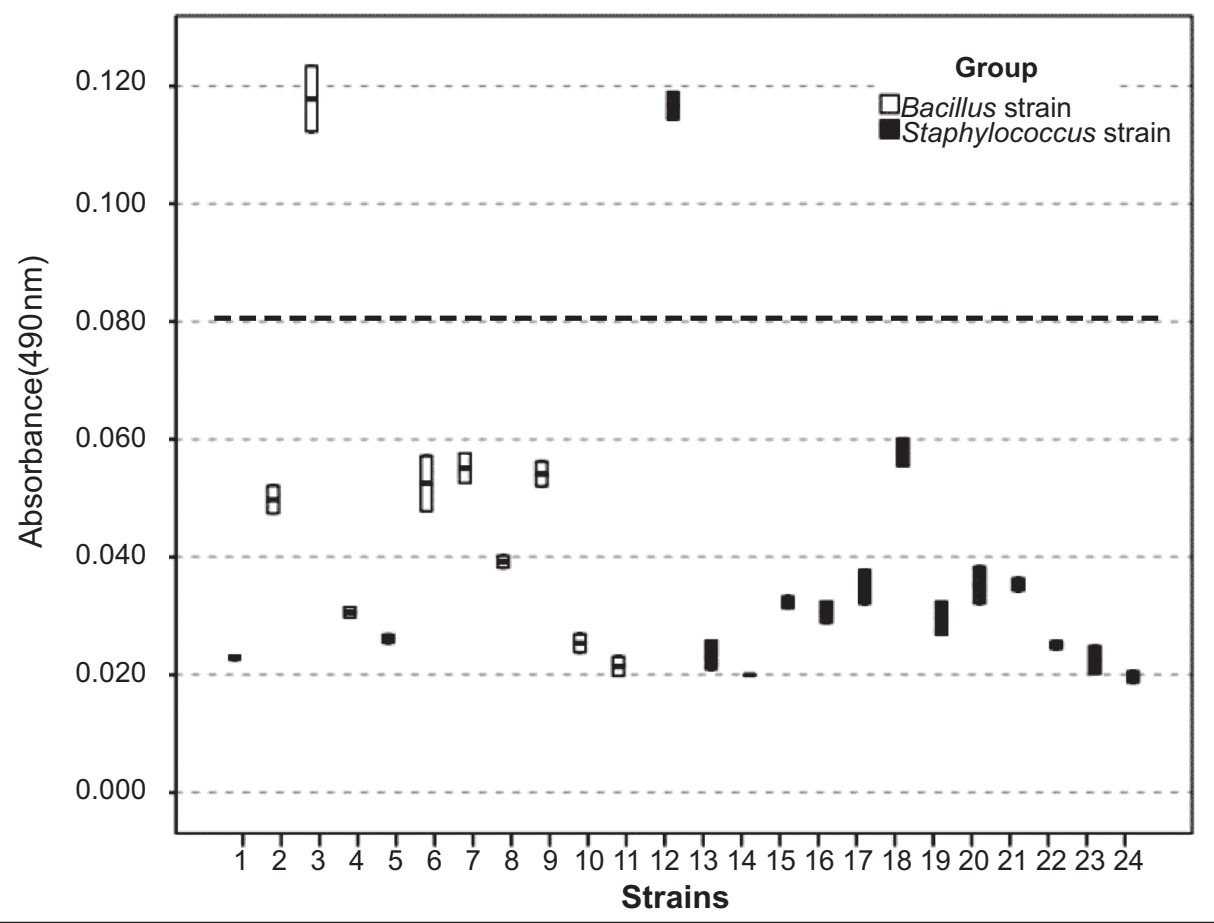

FIGURE 1. (A): Anti-microbial and anti-biofilm activity of medicinal plants from Northwestern Argentina against native isolates from the genera Bacillus and Staphylococcus. (B): A total of 53 spore-forming bacteria were isolated from natural environments and 22 coagulase-negative Staphylococcus (CoNS) were isolated from a dialysis center. Of these, 24 were selected as biofilm producers. The best biofilm producing strains were identified as Bacillus sp. + Mcn 4 (strain 3) and Staphylococcus sp. Mcr1 (strain 12) (p < 0.01). MIC: miminimum inhibitory concentration; SIC: sub-inhibitory concentration. 
showed SIC values between $15.62-62.5 \mu \mathrm{g} / \mathrm{ml}$ against this microorganism.

The $L$. divaricata extract showed remarkable activity against the genus Staphylococcus, with an SIC value equal to that of gentamicin $(15.62 \mu \mathrm{g} / \mathrm{ml})$, which was used as the reference antibiotic. Furthermore, T. absinthioides extract showed similar antimicrobial activity against Staphylococcus sp. Mcr1 to that of chloramphenicol (Table 2).

\section{Effect of plant extracts on biofilm formation}

The anti-biofilm activity of the plant extracts on Bacillus sp. Mcn4 and Staphylococcus sp. Mcr1 was also tested at selected SIC values.

The best anti-biofilm activity (66\%) against Bacillus sp. Mcn 4 was observed with the extract from T. absinthioides at $100 \mu \mathrm{g} / \mathrm{ml}$ (Figure 2A) and with $L$. divaricata extract across the entire range evaluated $(10-100 \mu \mathrm{g} / \mathrm{ml})$, with no significant differences observed for the latter extract across the extract concentrations evaluated $(\mathrm{p}=0.67)$ (Figure 2A).

Lycium chilense showed biofilm inhibition of $45 \%$ and $47 \%$ at $10 \mu \mathrm{g} / \mathrm{ml}$ and $50 \mu \mathrm{g} / \mathrm{ml}$, respectively, and the difference between these two concentrations was not significant $(\mathrm{p}=0.09)$. With T. minuta extract, the greatest inhibition $(50 \%)$ was observed at $100 \mu \mathrm{g} / \mathrm{ml}$, while for $S$. fasciculatus extract, no significant biofilm inhibition was observed (Figure 2A).

Anti-biofilm activity against Staphylococcus $\mathrm{sp}$. Mcr1 was also evaluated at selected SIC values (Figure 2B). The highest anti-biofilm activity was observed with $L$. chilense extract $(68 \%)$. In this case, anti-biofilm activity was dose dependent, with the highest inhibition observed at $50 \mu \mathrm{g} / \mathrm{ml}(\mathrm{p}=0.02)$. Tagetes minuta, T. absinthioides, and $L$. divaricata showed percentages of anti-biofilm activity with values between $55 \%$ and $62 \%$ (Figure 2B). For these extracts, no significant difference was observed between the two concentrations evaluated $(10 \mu \mathrm{g} / \mathrm{ml}$ and $50 \mu \mathrm{g} / \mathrm{ml}: \mathrm{p}=0.17, \mathrm{p}=0.05$, and $\mathrm{p}=0.59$ for T. minuta, T. absinthioides, and L. divaricata, respectively). As also observed against the genus Bacillus, S. fasciculatus extract showed only a low level of biofilm inhibition activity (Figure 2B).

\section{Effect of plant extracts on cell adherence}

The anti-adherence effects of the plant extracts were also evaluated. Samples selected for testing included the plant extract concentrations that had previously shown the most effective inhibition of biofilm (Figure 2).

The anti-adherence effects of $T$. absinthioides and L. divaricata extracts against Bacillus sp. Mcn 4 were found to be lower than their anti-biofilm activity, indicating that their ability to inhibit biofilm formation took place during a step subsequent to cell adherence (Figure 3A). The percentage of anti-adherence observed with $T$. minuta and $L$. chilense extracts reflected a difference only of $22 \%$ and $10 \%$, respectively, between antiadherence and biofilm inhibition (Figure 3A).

Schinus fasciculatus showed the same percentage of antiadherence effect as its percentage of anti-biofilm activity, with no significant difference observed between these $(p=0.55)$. Thus, for this plant extract, the inhibition of biofilm formation could be related to cell adherence.
In contrast, all plant extracts tested showed low antiadherence percentages against Staphylococcus sp. Mcr1, suggesting that their biofilm inhibition abilities may be related to a later step in biofilm formation. In all of these cases, the anti-biofilm effect was more than $50 \%$ higher than the antiadherence effect (Figure 3B).

\section{DISCUSSION}

The more potent antimicrobial activities observed for plant extracts were against the Staphylococcus strain. The antimicrobial activities produced by extracts of the genera Schinus and Lycium against Staphylococcus sp. Mcrl were comparable to those observed for gentamicin. This antimicrobial effect of the genus Schinus against Staphylococcus was also observed by Yao et al. ${ }^{(19)}$ and Gehrke et al. ${ }^{(33)}$, with both of these sources reporting an MIC value of $125 \mu \mathrm{g} / \mathrm{ml}$. However, in the present work, a more effective MIC of $31.25 \mu \mathrm{g} / \mathrm{ml}$ (Table 2) was observed. The similarities in the activities observed for S. fasciculatus and L. chilense could be due to the presence of flavonoids in both extracts. The antibacterial properties of these compounds are increasingly being reported, and raw extracts from plants with a history of use in traditional medicine have now been screened for antimicrobial activities by numerous research groups ${ }^{(34)(35)}$. However, it is also possible that the high antimicrobial activity shown by $S$. fasciculatus was due to disruption of the bacterial membrane caused by the presence of terpenoids, which inhibit Adenosine triphosphate (ATP) synthesis ${ }^{(36)(37)}$.

However, ethanolic extract of $L$. divaricata showed potent antimicrobial activity against Staphylococcus sp. Mcr1. Davicino et al. ${ }^{(18)}$ have reported that the fraction obtained from an ethanolic extract of $L$. divaricata contained several phenolic compounds, which may be responsible for the cytotoxicity observed against the Staphylococcus genus.

The antimicrobial activity observed with $T$. minuta and T. absinthioides may be due to the presence, not only of flavonoids, but also of essential oils of the family Asteraceae (to which these species belong; Table 1), which have been reported as compounds with antimicrobial activity ${ }^{(38)(39)}$.

The SIC values determined for each plant extract were used to evaluate biofilm inhibition.

Biofilm eradication is difficult to achieve because of host defenses and inherent resistance to antibiotics and biocides. Furthermore, there are several mechanisms used to explain the resistance of biofilms to antimicrobials ${ }^{(40)}$, which makes it difficult to predict the behavior of biofilm cells. In the present study, the anti-biofilm activity of plant extracts at SIC was evaluated after $24 \mathrm{~h}$ and the percentage of biofilm inhibition were observed (Figure 2). By comparing the values obtained, it can be seen that plant extract concentrations significantly affected the removal and/or inactivation of biofilms.

Extracts from these medicinal plants may influence biofilm formation by damaging microbial membrane structures ${ }^{(4)}$, inhibiting peptidoglycan synthesis, and/or modulating quorum sensing ${ }^{(41)}$. With regard to the last of these mechanisms, several approaches involving quorum interference have 
(A)

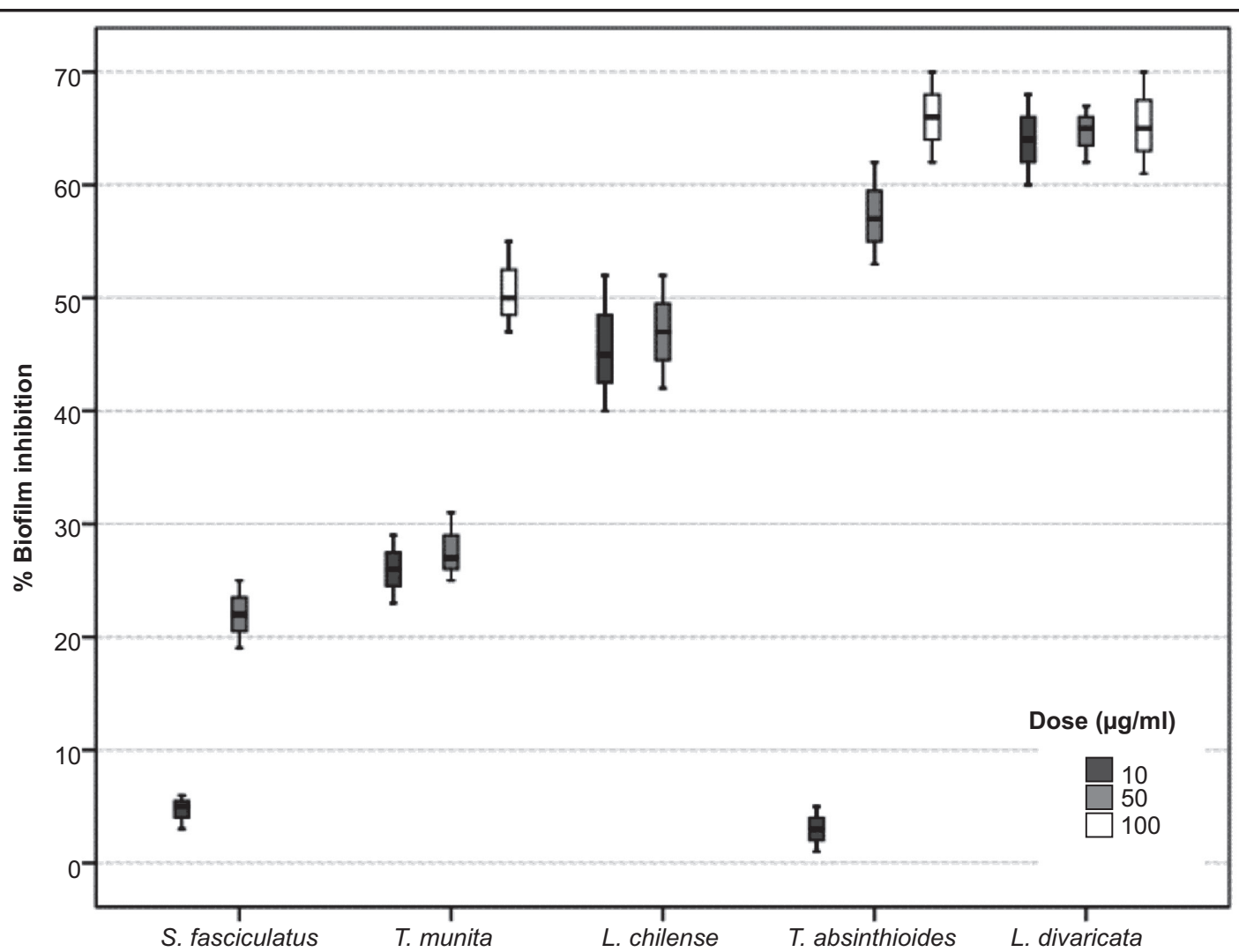

(B)

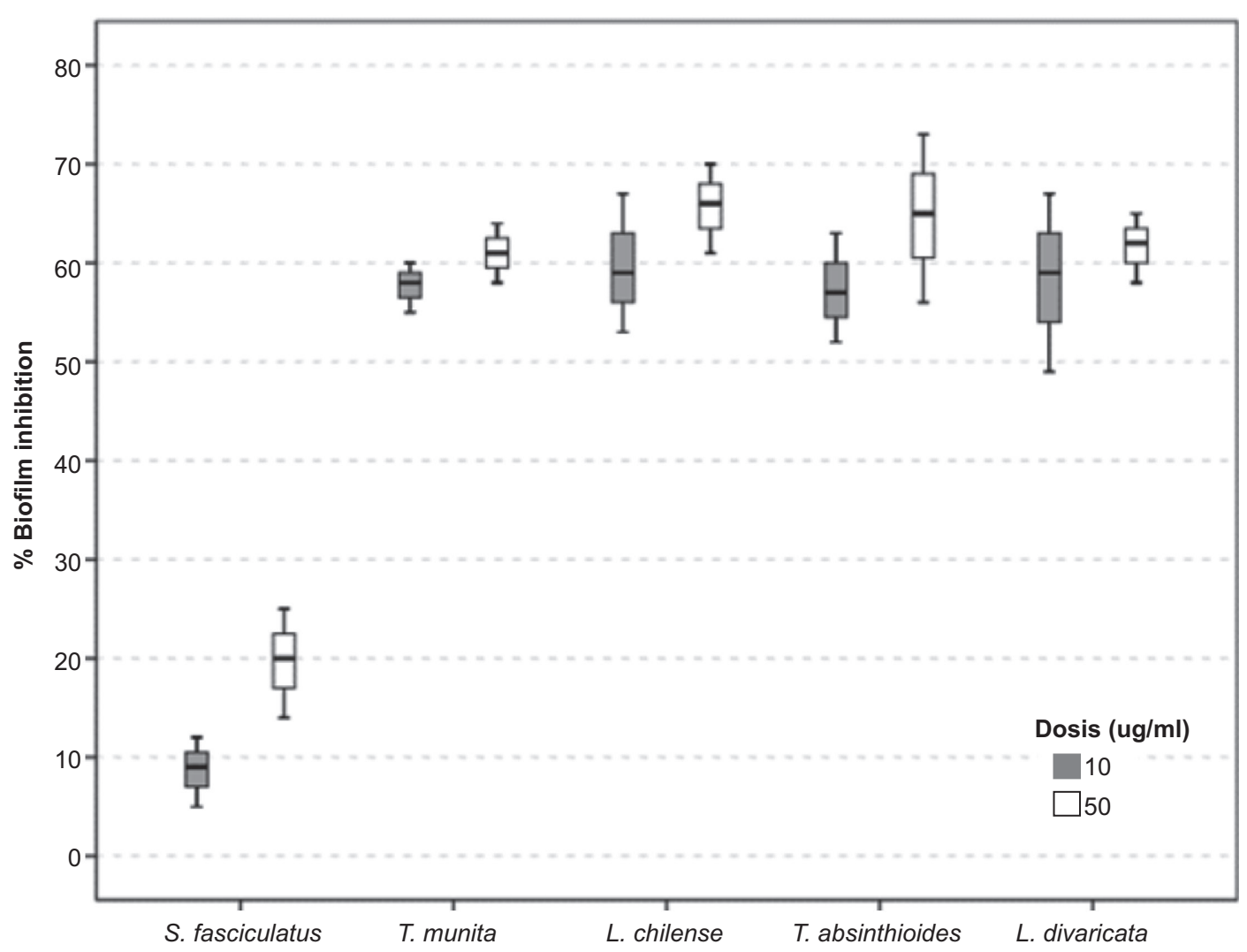

FIGURE 2. Anti-biofilm effects of extracts of traditional medicinal plants from Northwestern Argentina against. (A): Bacillus sp. Mcn4 and (B): Staphylococcus sp. Mcr1. Sub-inhibitory concentrations from $10-100 \mu \mathrm{g} / \mathrm{ml}$ were used. The values are expressed as percentages of bacterial biofilm inhibition by each plant extract, compared with the control (no plant extract) and expressed as means \pm standard deviation of triplicate assays. 
(A)

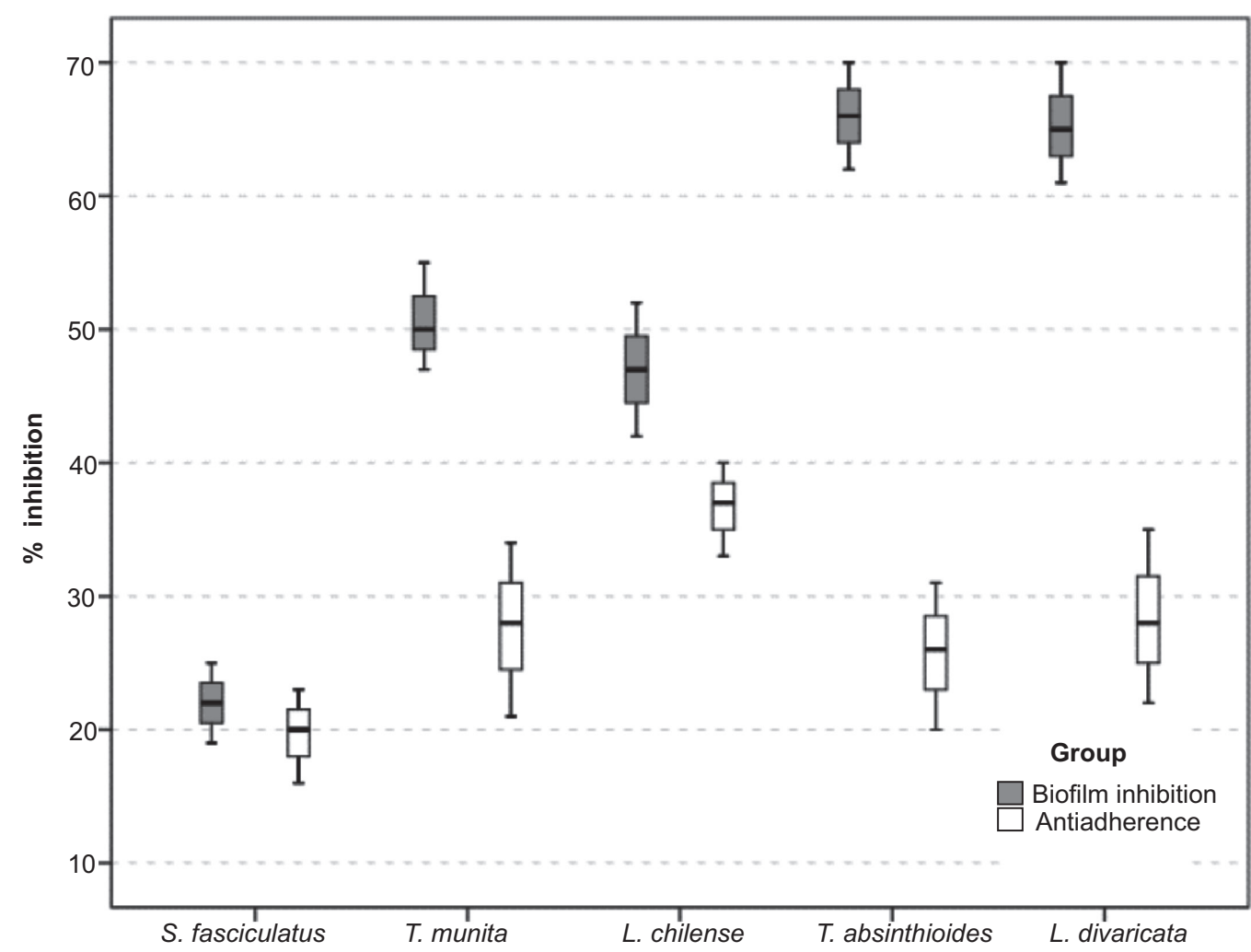

(B)

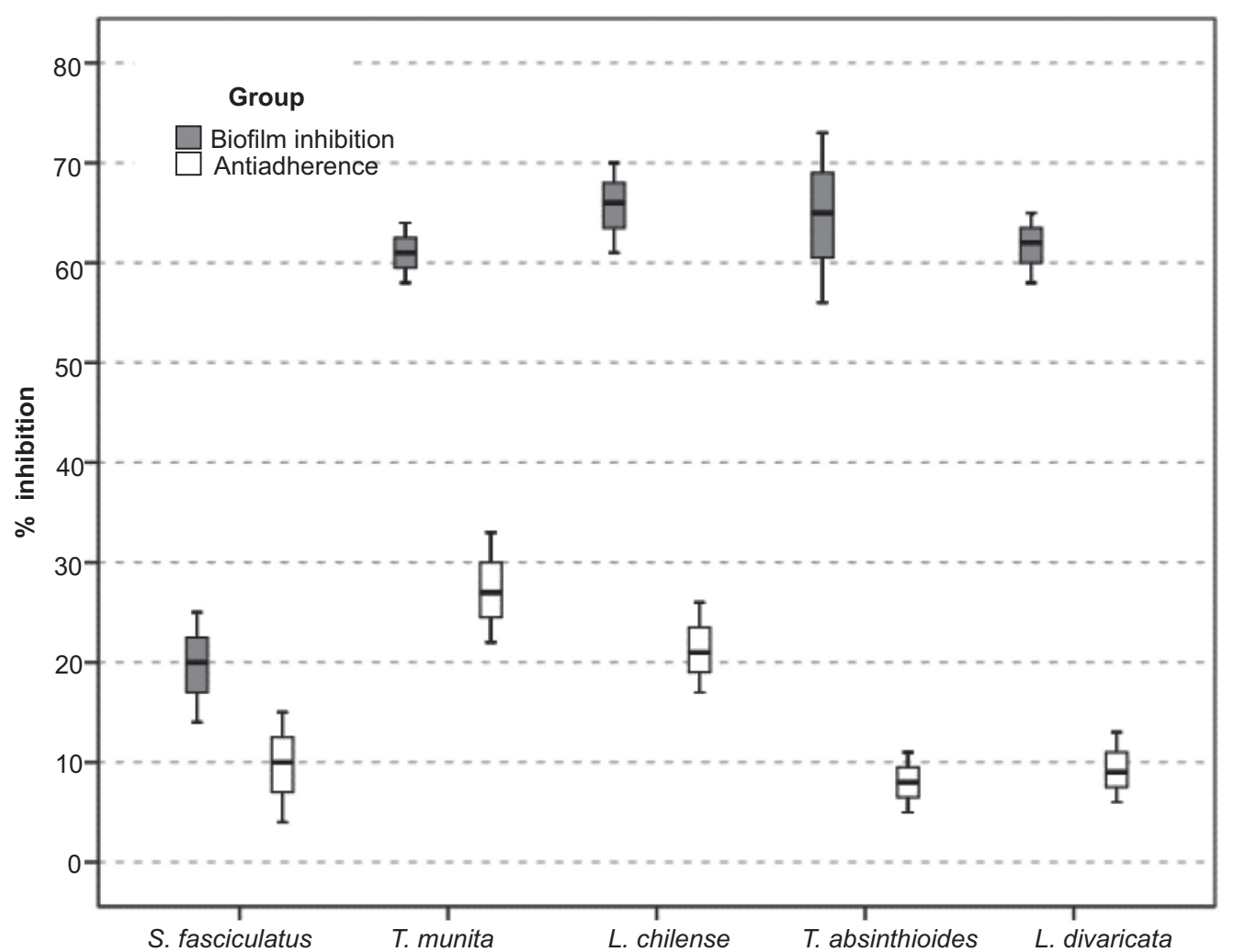

FIGURE 3. Anti-adherence effects against (A): Bacillus sp. Mcn4 and (B): Staphylococcus sp. Mcr1 cells. Values are expressed as percentages of cell antiadherence inhibition compared with anti-biofilm inhibition. The values are expressed as means \pm standard deviation of triplicate assays. 
been studied and they represent the most recent strategies to counteract staphylococcal infections, among others. Quorum interference can be achieved by several alternative strategies, including quorum sensing disruption through inhibition of signal molecule biosynthesis, signal molecule inactivation, and blockage of signal transduction ${ }^{(41)(42)}$. In fact, flavonoids are among the compounds that exert anti-biofilm effects via quorum sensing inhibition ${ }^{(43)}$. In the present study, all plant extracts that showed biofilm inhibition contain flavonoids, and as such, these compounds may be responsible for the biofilm inhibition observed, although further studies are required to investigate this.

Biofilm formation occurs stepwise, and one step of relevant importance is cell adhesion that occurs prior to biofilm formation $^{(44)}$. In view of the importance of this step in biofilm production, the anti-adherence effects of the plant extracts under study were also evaluated.

For S. fasciculatus, the inhibition of biofilm formation observed may be related to cell adherence. Considering that adherence is a prerequisite for colony formation, preventing bacterial adhesion would appear to be an ideal strategy for reducing biofilm formation ${ }^{(44)}$.

For the plant extracts evaluated in this study, anti-biofilm and anti-adherence properties against the genus Bacillus and anti-biofilm activity against CoNS isolates have not been previously reported. These findings may represent novel, alternative approaches to biofilm control, especially in relation to infectious diseases caused by $\mathrm{CoNS}^{(1)}$. Furthermore, the biodeterioration of metals in industrial processes has detrimental effects on the environment with economic implications. The production of biofilm by Bacillus spp. affects the level of metal corrosion in industrial processes ${ }^{(45)}$. Thus, the development of a preventive strategy against bacterialmediated corrosion is necessary.

The plant extracts studied here showed antimicrobial activity as well as biofilm inhibition against the genera Bacillus and Staphylococcus. These findings may represent the first of many steps towards the development of new antimicrobial and antibiofilm drugs using extracts from plants used in traditional folk medicine in northwestern Argentina. Given the importance of developing new strategies for controlling the growth of biofilm because of its pathogenic association with several diseases or influence on the level of metal corrosion in industrial processes, further investigation of the natural biofilm inhibition exhibited by Argentinean plant extracts is clearly warranted.

\section{Acknowledgments}

We offer our deepest thanks to the institutions that provided technical support for the development and implementation of this studyNational Scientific and Technical Research Council (CONICET) and National University of Tucumán (UNT).

\section{Conflict of Interest}

The authors declare that they have no conflicts of interest.

\section{Financial Support}

The present work was supported by Agencia de Promoción Científica y Tecnológica (PICT 2012-2914) Préstamo del Banco Internacional de Desarrollo (BID) and Programa de Investigación de la Universidad Nacional de Tucumán (PIUNT E 548).

\section{REFERENCES}

1. de Allori MCG, Jure MA, Romero C, de Castillo MEC. Antimicrobial resistance and production of biofilms in clinical isolates of coagulase-negative Staphylococcus strains. Biol Pharm Bull 2006; 29:1592-1596.

2. Bloomfield SF. Significance of biocide usage and antimicrobial resistance in domiciliary environments. J Appl Microbiol 2002; 92:144-157.

3. Monte J, Abreu AC, Borges A, Simões LC, Simões M. Antimicrobial activity of selected phytochemicals against Escherichia coli and Staphylococcus aureus and their biofilms. Pathogens 2014; 3:473-498.

4. Cox SD, Mann CM, Markham JL, Bell HC, Gustafson JE, Warmingto JR, et al. The mode of antimicrobial action of the essential oil of Melaleuca alternifolia (tea tree oil). J Appl Microbiol. 2000; 88:170-175.

5. Erazo S, Delporte C, Negrete R, Garcia R, Zaldivar M, Ittura G, et al. Constituents and biological activities of Schinus polygamus. J Ethnopharmacol 2006 107:395-400.

6. Pérez RM, Hernández H, Hernández S. Antioxidant activity of Tagetes erecta essential oil. J Chil Chem Soc 2006; 51:883-886.

7. Quave CL, Plano LRW, Pantuso T, Bennett BC. Effects of extracts from Italian medicinal plants on planktonic growth, biofilm formation and adherence of methicillin-resistant Staphylococcus aureus. J Ethnopharmacol 2008; 118:418-428.

8. Tereschuk ML, Baigorí MD, de Figueroa LIC, Abdala LR. Flavonoids from argentine species of Tagetes (Asteraceae) with antimicrobial activity. Methods Mol Biol 2004; 268:317-330.

9. Zampini IC, Cudmani N, Isla MI. Actividad antimicrobiana de plantas medicinales argentinas sobre bacterias antibióticoresistentes. Acta Bioq Clin Latinoam 2007; 41:385-393.

10. Vacheva A, Mustafa B, Staneva J, Marhova M, Kostadinova S, Todorova M, et al. Effects of extracts from medicinal plants on biofilm formation by Escherichia coli urinary tract isolates. Biotechnol Biotec Eq 2011; 25 (suppl):92-97.

11. Hobby GH, Quave CL, Nelson K., Compadre CM, Beenken KE, Smeltzer MS. Quercus cerris extracts limit Staphylococcus aureus biofilm formation. J Ethnopharmacol 2012; 144:812-815.

12. Costerton JW, Cheng KJ, Geesey GG, Ladd TI, Nickel JC, Dasgupta M, et al. Bacterial biofilms in nature and disease. Annu Rev Microbiol 1987; 41:435-464.

13. Hall-Stoodley L, Stoodley P. Evolving concepts in biofilm infections. Cell Microbiol 2009; 11:1034-1043.

14. Lopez D, Vlamakis H, Kolter R. Biofilms. Cold Spring Harb Perspect Biol 2010; 2:a000398.

15. Rendueles O, Kaplan JB, Ghigo JM. Antibiofilm polysaccharides. Environ Microbiol 2013; 15:334-346.

16. Miller JH. Experiments in molecular genetics. New York: Cold Spring Harbor Laboratory, Cold Spring Harbor; 1972. 466p.

17. Palacio L, Lloret CV, Baeza C, Ortiz L, Brunetti P, Cantero JJ, et al. Determinación de metabolitos de interés farmacológico en plantas micropropagadas de Larrea divaricata Cav. Bol Latinoam y del Caribe Plantas Med y Aromat 2007; 6:405-406. 
18. Davicino R, Martino R, Anesini C. Larrea divaricata Cav: scientific evidence showing its beneficial effects and its wide potential application. Bol Latinoam y del Caribe Plantas Med y Aromat 2011; 10:92-103.

19. Yao X, Peng Y, Xu LJ, Li L, Wu QL, Xiao PG. Phytochemical and biological studies of Lycium medicinal plants. Chem Biodivers 2011; 8:976-1010.

20. Yuequin Z, Recio MC, Manez S, Giner RM, Cerda-Nicolas M, Rios JL. Isolation of two triterpenoids and a biflavanone with antiInflammatory activity from Schinus molle fruit. Planta Med 2003; 69:893-898.

21. Díaz C, Quesada S, Brenes O, Aguilar G, Cicció JF. Chemical composition of Schinus molle essential oil and its cytotoxic activity on tumour cell lines. Nat Prod Res 2008; 22:1521-1534.

22. Gupta MP. 270 Plantas medicinales iberoamericanas. Talleres de Editorial Presencia Ltda; Santa Fe de Bogotá: Colombia; 1995. p. 347.

23. Tereschuk ML, Riera MVQ, Castro GR, Abdala LR. Antimicrobial activity of flavonoids from leaves of Tagetes minuta. J Ethnopharmacol. 1997; 56:227-232.

24. Scrivanti RL, Zunino MP, Zygadlo JA. Tagetes minuta and Schinus areira essential oils as allelopathic agents. Biochem Syst Ecol 2003; 31:563-572.

25. Srinivasan D, Nathan S, Suresh T, Permalsamy PL. Antimicrobial activity of certain Indian medicinal plants used in folkloric medicine. J Ethnopharmacol. 2001; 74:217-220.

26. Lima B, Aguero MB, Zygadlo J, Tapia A, Solis C, Rojas De Arias A, et al. Antimicrobial activity of extracts, essential oil and metabolites obtained from Tagetes mendocina. J Chil Chem Soc 2009; 54:68-72.

27. Schmeda-Hirschmann G, Tapia A, Theoduloz C, Rodríguez J, Lopez S, Feresin GE. Free radical scavengers and antioxidants from Tagetes mendocina. Z Naturforsch C 2004; 59:345-353.

28. Gleiser RM, Bonino MA, Zygadlo JA. Repellence of essential oils of aromatic plants growing in Argentina against Aedes aegypti (Diptera: Culicidae). Parasitol Res 2011; 108:69-78.

29. García MV, Matias J, Cavalcante Barros J, Pires de Lima D, da Silva Lopes R, Andreotti R. Chemical identification of Tagetes minuta Linnaeus (Asteraceae) essential oil and its acaricidal effect on ticks. Rev Bras Parasitol Vet 2012; 21:405-411.

30. García CC, Talarico L, Almeida N, Colombres S, Duschatzky C, Damonte EB. Virucidal activity of essential oils from aromatic plants of San Luis, Argentina. Phytother Res 2003; 17:1073-1075.

31. Visintini Jaime MF, Redko F, Muschietti LV, Campos RH, Martino VS, Cavallaro LV. In vitro antiviral activity of plant extracts from Asteraceae medicinal plants. Virology J 2013; 10:245.

32. Christensen GD, Simpson WA, Younger JJ, Baddour LM, Barrett FF, Melton DM, et al. Adherence of coagulase-negative staphylococci to plastic tissue culture plates: a quantitative model for the adherence of staphylococci to medical devices. J Clin Microbiol 1985; 27: 956-1006.

33. Gehrke ITS, T Neto A, Pedroso M, Mostardeiro CP, Da Cruz IBM, Silva UF, et al. Antimicrobial activity of Schinus lentiscifolius (Anacardiaceae). J Ethnopharmacol 2013; 148:486-491.

34. Aristimuño Ficoseco ME, Vattuone MA, Audenaert K, Catalán CA, Sampietro DA. Antifungal and antimycotoxigenic metabolites in Anacardiaceae species from northwest Argentina: isolation, identification and potential for control of Fusarium species. J Appl Microbiol. 2014; 116:1262 -1273.

35. Cushnie TP, Lamb AJ. Antimicrobial activity of flavonoids. Int $\mathrm{J}$ Antimicrob Agents 2005; 26:343-356.

36. Gyawali R, Ibrahim SA. Impact of plant derivatives on the growth of foodborne pathogens and the functionality of probiotics. Appl Microbiol Biotechnol 2012; 95:29-45.

37. Morán A, Gutiérrez S, Martínez-Blanco H, Ferrero MA, Monteagudo-Mera A, Rodríguez-Aparicio LB. Non-toxic plant metabolites regulate Staphylococcus viability and biofilm formation: a natural therapeutic strategy useful in the treatment and prevention of skin infections. Biofouling 2014; 30:1175-1182.

38. Ali NA, Sharopov FS, Al-Kaf AG, Hill GM, Arnold N, Al-Sokari SS, et al. Composition of essential oil from Tagetes minuta and its cytotoxic, antioxidant and antimicrobial activities. Nat Prod Commun 2014; 9:265-268.

39. Kouidhi B, Mohammed Y, Qurashi AA, Chaieb K. Drug resistance of bacterial dental biofilm and the potential use of natural compounds as alternative for prevention and treatment. Microb Pathog 2015; 80:39-49.

40. Sillankorv S, Oliveira R, Vieira MJ, Sutherland I, Azeredo $J$. Bacteriophage $\Phi \mathrm{S} 1$ infection of Pseudomonas fluorescens planktonic cells versus biofilms. J Biofouling 2004; 20:133-138.

41. Hartmann A, Rothballer M, Hense BA, Schröder P. Bacterial quorum sensing compounds are important modulators of microbeplant interactions. Front Plant Sci 2014; 5:131.

42. Rampioni G, Leoni L, Williams P. The art of antibacterial warfare: deception through interference with quorum sensing-mediated communication. Bioorg Chem. 2014; 55:60-68.

43. Manner S, Skogman M, Goeres D, Vuorela P, Fallarero A. Systematic exploration of natural and synthetic flavonoids for the inhibition of Staphylococcus aureus biofilms. Int J Mol Sci 2013; 14:19434-19451.

44. Kostakioti M, Hadjifrangiskou M, Hultgren SJ. Bacterial biofilms: development, dispersal, and therapeutic strategies in the dawn of the postantibiotic era. Cold Harb Perspect Med 2013; 3:a010306.

45. Lin J, Madida BB. Biofilms affecting progression of mild steel corrosion by Gram positive Bacillus sp. J Basic Microbiol 2015; 55:1168-1178. 